\title{
The necessity of rehabilitation in children with Down syndrome
}

\author{
Elena AMĂRICĂI' ${ }^{1}$, Liliana CĂȚAN ${ }^{2}$, Florentina LEORINȚI ${ }^{3}$
}

\begin{abstract}
Introduction: Children with Down syndrome have associated impairments of the musculoskeletal system and connective tissue (joint hypermobility), and of the neurologic system (hypotonia, mental retardation, developmental delay). Aim: We conducted a retrospective study that had in view the quantification of the number of children suffering from Down syndrome who attended rehabilitation programmes in the Rehabilitation Department of "Louis Țurcanu” Emergency Children's Hospital Timisoara for a 3-year period (between November 2016 and October 2019). Methods: The study included 21 children with Down syndrome; their age ranged from 2 weeks to 15 years, with $52 \%$ of the children being in the $0-12$ months group. All patients were included in a rehabilitation programme of the outpatient Rehabilitation Department (with 10 daily sessions) every 6 months. Results: We point out the importance of the rehabilitation team in the management of children with Down syndrome. Conclusion: The physical therapy programme should be for a long term, it should be started as early as possible (even in the first weeks of life) and followed continuously through the entire growth period and also during adulthood.
\end{abstract}

Key words: Down syndrome, rehabilitation, interdisciplinary management

\section{Rezumat}

Introducere: Copiii diagnosticați cu sindromul Down prezintă asociat afectări ale sistemului musculoscheletal (de exemplu, hiperlaxitate articulară), dar și o serie de manifestări neurologice (hipotonie musculară generalizată, retard mental, retard de dezvoltare neuromotorie). Scop: Am efectuat un studiu retrospectiv ce a avut în vedere cuantificarea numărului de cazuri de copii diagnosticați cu sindrom Down care au urmat programe de reabilitare medicală în cadrul Compartimentului de Recuperare al Spitalului Clinic de Urgență pentru Copii „Louis Țurcanu” Timișoara pe o perioadă de 3 ani (11.2016-10.2019). Metode: Studiul a inclus 21 de copii a căror vârsta a fost cuprinsă între 2 săptămâni și 15 ani. 52\% dintre copii au avut vârsta mai mică de 1 an. Copiii au urmat programe de reabilitare medicală în regim ambulator sub formă de 10 ședinte la fiecare 6 luni. Rezultat: Subliniem importanța echipei de reabilitare medicală în managementul copiilor cu sindrom Down. Concluzii: Kinetoterapia trebuie să fie una de lungă durată, începută cât mai precoce (chiar în primele săptămâni de viață) și continuată pe întreaga perioadă de creștere a copilului și de asemenea în perioada de adult.

Cuvinte cheie: sindromul Down, reabilitare medicală, management interdisciplinar

\footnotetext{
1 MD, PhD, Associate professor, Department of Rehabilitation, Physical Medicine and Rheumatology, "Victor Babes" University of Medicine and Pharmacy Timișoara; “Louis Țurcanu” Emergency Children's Hospital, Timisoara, Romania; e-mail: amaricai.elena@umft.ro

${ }^{2} \mathrm{MD}, \mathrm{PhD}$, Assistant professor, Department of Rehabilitation, Physical Medicine and Rheumatology, "Victor Babes" University of Medicine and Pharmacy, Timișoara; "Louis Țurcanu” Emergency Children's Hospital, Timisoara, Romania

3 Bachelor in physical therapy, “Victor Babes” University of Medicine and Pharmacy, Timișoara, Romania
} 


\section{Introduction}

Down syndrome (trisomy 21) is the most common aneuploid condition compatible with survival. Children with Down syndrome have associated impairments of the musculoskeletal system and connective tissue (joint hypermobility, hypoplastic pelvis, wide gap between toes 1 and 2, simian creases), and of the neurologic system (mild microcephaly, hypotonia, mental retardation, developmental delay) [1-3].

The aim of our study was to quantify the number of paediatric patients suffering from Down syndrome that have followed rehabilitation during a 3-year period. Another objective was to point out the importance of the rehabilitation programmes with adequate adjustments for the age and motor development of children with Down syndrome.

\section{Material and Methods}

We conducted a retrospective study that had in view the quantification of the number of children suffering from Down syndrome who attended rehabilitation programmes in the Rehabilitation Department of "Louis Țurcanu" Emergency Children's Hospital Timisoara for a 3-year period (between November 2016 and October 2019).

In our research, we also included a prospective study that aimed to record the effects of rehabilitation on the motor development of different age children with Down syndrome.

The following demographic and clinical characteristics related to patients were collected: age, gender, musculoskeletal disorders and other pathologies.

The studied patients followed a rehabilitation programme in the outpatient Rehabilitation Department (for 10 daily sessions) every 6 months. The rehabilitation objectives were according to the patients' age. In the neonates we had in view the progressive strengthening of the trunk and limb muscles, with specific exercises for the trunk extensors. With the increase of children's age, the physical exercise programme especially focused on turning from prone to supine and from supine to prone, acquiring the independent sitting position, lifting alone in the sitting position, creeping, crawling on all fours, standing with support, pulling self to stand, walking with support, standing alone and, afterwards, walking alone.

For young infants the rehabilitation objectives were the following: independent walking, balance training and even acquiring an improved running pattern.

In the 7-10 year and 11-15 year groups the rehabilitation aimed the following: strengthening of the trunk and limb muscles, sprain prevention, postural correction, increase of the functional capacity, and progressive exercise training.

At the inclusion in the rehabilitation programme, the parents of children older than 1 year filled in the Down Syndrome Specialty Clinic: Intake Questionnaire [4]. The questionnaire collects general data, information related to speech pathology, genetics, nutrition, community resources, education, audiology, psychology, physical and occupational therapy, including fine and motor gross function, sensory processing, behaviour, self-care and play.

\section{Results}

The retrospective study recorded a number of 21 children suffering from Down syndrome who attended rehabilitation in our department.

Even though this does not seem like a high number of patients, it should be mentioned that genetic diseases are, in most of the cases, rare and very rare, with Down syndrome being one of the most frequent ones.

The children's age ranged from 2 weeks to 15 years, with $52 \%$ of the children being in the $0-12$ months group. The patients' demographic characteristics are presented in Table I. 
Table I. Patients' demographic characteristics

\begin{tabular}{ll}
\hline Variables & \\
\hline Number of patients & 21 \\
Females (\%) & $10(47.6 \%)$ \\
Males (\%) & $11(52.4 \%)$ \\
\hline Age groups & \\
0-12 months (\%) & $11(52.4 \%)$ \\
1-3 years (\%) & $2(9.5 \%)$ \\
4-7 years (\%) & $2(9.5 \%)$ \\
8-10 years (\%) & $4(19 \%)$ \\
11-15 years (\%) & $2(9.5 \%)$ \\
\hline Environment & \\
Urban (\%) & $18(85.7 \%)$ \\
Rural (\%) & $3(14.3 \%)$ \\
\hline
\end{tabular}

The associated musculoskeletal disorders and other pathologies are presented in Table II. 10 of the 21 patients had different disorders (musculoskeletal, cardiac, neurologic and endocrine). Scoliosis was recorded in adolescents; the degree of scoliosis was mild, with a Cobb angle ranging from $12^{\circ}$ to $19^{\circ}$. The child with bilateral congenital hip dislocation has not followed surgery. The children suffering from Fallot tetralogy and atrial septal defect underwent cardiac surgery.

Table II. Associated pathologies

\begin{tabular}{ll}
\hline Pathologies & $\begin{array}{l}\text { Number of } \\
\text { cases }\end{array}$ \\
\hline Musculoskeletal disorders & $5(23.8 \%)$ \\
Scoliosis & $2(9.5 \%)$ \\
Congenital hip dislocation & $1(4.7 \%)$ \\
Talus valgus foot & $1(4.7 \%)$ \\
Pectus excavatum & $1(4.7 \%)$ \\
\hline Cardiac disorders & $3(14.2 \%)$ \\
Fallot tetralogy & $1(4.7 \%)$ \\
Ventricular septal defect & $1(4.7 \%)$ \\
Atrial septal defect & $1(4.7 \%)$ \\
\hline Other disorders & $2(9.5 \%)$ \\
Neurologic (paraparesis) & $1(4.7 \%)$ \\
Endocrine (congenital & $1(4.7 \%)$ \\
hypothyroidism) & \\
\hline
\end{tabular}

10 parents filled in the questionnaire. In the 1-3 years group, the two children presented clumsiness in walking, with axial hypotonia. They frequently had the need to have something in their mouth and also had chewing problems.
In the 4-7 years group, the two children had difficulties in writing and had an awkward crayon holding. They also had difficulties in holding the spoon and manipulating game pieces. They presented clumsiness in running and fear of climbing. They fatigued relatively easily and also had toileting problems. They needed extra help for dressing.

The children in the 8-10 years group had difficulties in writing, in holding the spoon and fork, and in using scissors. They presented clumsiness in running, fear of heights and difficulties using playground equipment.

The two adolescents had difficulties in writing, in holding the fork and in using scissors. They fatigued after walking an average distance.

None of the children had difficulties playing with others. They all prefer to play or interact with other children of their age.

All children had speech problems. They were recommended to follow an age specific speech therapy.

The compliance to rehabilitation was very good as 19 of the 21 patients (90\%) continued the rehabilitation programme.

After one year we aim to assess once again the children, by using the Down Syndrome Specialty Clinic: Intake Questionnaire. The second evaluation was not included at this point as not all children followed a 1-year rehabilitation period.

\section{Discussions}

Physical exercise has an important role in the rehabilitation of children with Down syndrome. It should be started in the first months of life in order to achieve an improved neuromotor development. It is considered that the start of rehabilitation as early as possible will lead to a higher level of independence. This fact also has in view the prevention and correction of associated deficiencies.

The study of Malak et al. (2015) assessing 79 children with Down syndrome (average age 6 years and 3 months \pm 4 years and 6 months) showed that these patients had delayed motor development, especially concerning the standing position and walking ability. The authors recommended that both balance and motor functions should be 
considered in the physical therapy of children with Down syndrome [5].

The play therapy used in the rehabilitation programme has a great success among the children with Down syndrome. They should be included in the groups of children with the same disability, but also in groups with children without disabilities. The training and engagement of tasks are favoured by the wish of imitation that is specific for children with Down syndrome.

Occupational therapy is extremely important. It has in view the following: training of the gross motor skills, but especially of the fine motor skills, training of the oral motor movements (movement of the oral cavity muscles, movements of the lips, tongue and maxillary, including the sucking, bite, chewing and licking), training of self-care activities (dressing, feeding, toileting), sensorial integration (ability to receive, sort and respond to environmental information), and planning of motor tasks (ability to plan, implement and divide the sequences of motor tasks) [6].

\section{References}

1. Epstein C.J. (1989). Down syndrome, trisomy 21, In Scriver C.R., Beaudet A.L., Sly W.S., Valle D. (Eds). Metabolic basis of inherited disease, New York: McGraw-Hill, 291-326.

2. Jones K.L. (1997). Smith's recognizable patterns of human malformation, $5^{\text {th }}$ ed. Philadelphia: W.B. Saunders Co., 8-14.

3. Campbell S.K., Vander Linden D.W., Palisano R.J. (2006). Physical therapy for children, Elsevier, 230-231.

4. https://depts.washington.edu/chdd/ucedd/ctu_5/pdfs/DS SC_intake_questionnaire.pdf (accessed on 15 October 2016)

5. Malak R., Kostiukow A., Krawczyk-Wasielewska A., Mojs E., Samborski W. (2015). Delays in Motor Development in Children with Down Syndrome, Medical Science Monitor:
A recent study from 2019 including 40 children with Down syndrome (mean age at the start of the intervention: 7 months; range: 1-25 months) showed the fact that a very early motor rehabilitation may contribute to an improved development of gross motor movement [7].

In our study, we noticed a high addressability of children with Down syndrome towards the rehabilitation department, as well as a very good interdisciplinary teamwork among the geneticist, paediatrician, paediatric cardiologist, paediatric orthopaedics and rehabilitation team.

\section{Conclusions}

We point out the importance of the rehabilitation team in the management of children with Down syndrome. The physical therapy programme should be for a long term, it should be started as early as possible (even in the first weeks of life) and followed continuously through the entire growth period, and also during adulthood.

International Medical Journal of Experimental and Clinical Research, 21, 1904-1910.

6. Winders, P. C. Gross motor development and Down syndrome. http://www.ndss.org/en/Education-Development-Community-Life/Therapies--Development/Physical-Occupational-Therapy/\#gross (accessed on 22 September 2019).

7. Okada S., Uejo T., Hirano R., Nishi H., Matsuno I., Muramatsu T., Fujiwara M., Miyake A., Okada Y., Fukunaga S., Ishikawa Y. (2019). Assessing the Efficacy of Very Early Motor Rehabilitation in Children with Down Syndrome, The Journal of Pediatrics, 213, 227-231. 